\title{
A Review on Different Weed Management Approaches
}

\author{
Harmanpreet Kaur ${ }^{1}$, Gursharnpreet Singh Brar ${ }^{1}$ and Poonam Pandurang Shete ${ }^{2 *}$ \\ ${ }^{1}$ Department of Agronomy, School of Agriculture, Lovely Professional University Phagwara, \\ Punjab, India \\ ${ }^{2}$ Department of Plant $P$, Lovely Professional University Phagwara, Punjab, India
}

*Corresponding author

\begin{abstract}
A B S T R A C T
\section{Keywords}

Environment,

Fertilizer,

Integrated, Weed

etc.

Article Info

Accepted:

22 July 2019

Available Online:

10 August 2019

It was examined that weeds cause a lot of problems in the crop field. Weeds compete with the main crop for nutrients, water, food, space, sunlight etc. Weeds utilize the nutrients provided to the main crop and sometimes dominate the main crop. Some weeds are very noxious and they are harmful for both humans as well as animals. It is clearly revealed from studies done in field of weeds that use of herbicides used to control weeds cause many effects on soil as it leads to degradation in the quality of soil, water as well as it pollutes environment. And also repeated use of same herbicide makes the weeds resistant to that herbicide. Many ways used to control weeds like Mechanical control, Cultural control, Chemical control and Biological control. But now a days chemical control is too much widespread in which use of different herbicides done. Overuse of chemical fertilizers harms soil health as well as decrease quality of environment. So a new approach called Integrated Weed Management (IWM) came into light in which all the approaches are combinely used just to reduce the alone use of herbicides.
\end{abstract}

\section{Introduction}

Weeds have been known since the ancient times. Weeds may be defined as plants other than crop plant or any unwanted plant grown in the main field with crop plants. Weeds not only grow with the main crop but also compete with main crop for basic necessities like food, space, sunlight, nutrients etc. and cause a lot of loss in agricultural production (Das 2008). Weeds are impossible to totally eliminate from the main field as they spread through many ways like dispersal of dormant seeds, vegetative propagules etc. (Singh et al., 2014). The success of weed management process is directly related to agricultural success as a whole (David et al., 2012). Weeds can be considered as an important component of agriculture system and occupy a major proportion of resources available for plant growth (Oerke 2006). Improper management of weeds or if weeds are not controlled on proper time it leads to high reduction of crop yield and production cost also increase (Sharma 2014). Weeds cause reduction in yield upto $90 \%$ and sometimes 
due to weeds crop failure occurs. Earlier, to remove weeds main focus was given on crop rotation, cleaning of seeds, tillage practices etc. Cultural control means some modifications in cropping system just to $b$ avoid the effect of weeds on the main crop (Dubey 2014). On the other hand options for biological control are very few that's why its not too much adopted. So, in Physical control hand weeding or hand hoeing done and in Chemical control herbicides are used and this method to control weeds is too much popular among farmers. Overuse of chemical fertilizers and their effect on soil and environment has become a global issue. Efforts to manage weeds like cleaning of seeds, cleaning farm equipments, keeping irrigation channels clean etc. had been adopted by farmers since ancient times. The description of different weed control methods is given below:

\section{Cultural Control}

This method of weed control may be considered as one of the best and oldest method accepted worldwide and includes many techniques like irrigation, cover crop, intercropping, crop rotation, tillage, sowing and fertilizer application timing etc. (Kumar et al., 2014).

\section{Stale seedbed technique}

In this process, after preparing the field irrigation is given and then field is left vacant for sometime so that weeds can germinate. Those weeds can be removed from the field either by spraying herbicide or by doing tillage operations (Singh 2014). This technique is very useful to eliminate weeds or also to reduce crop weed competition (Sindhu et al., 2010). The success of this method depends upon several factors like species of weeds, condition of environment, way of preparing stale seedbed etc.

\section{Crop rotation}

Rotation of crops cause problems in the emergence of weeds as sowing dates or harvesting dates of different crops are different (Das et al., 2012).

For e.g rotation of crops like wheat, maize or soybean leads to decrease number of weeds (Teasdale et al., 2004).

\section{Time of sowing}

Early sowing of crops provides tough competition to weeds (Sindhu et al., 2010) as crops emerge before the weeds emerge and therefore, weeds donot get enough space, nutrients or light for growth (Cici et al., 2008). For e.g planting of rice crop during monsoon provides best yield and also number of weeds lessen.

\section{Method of sowing}

Sowing methods have great influence on lowering the weed population (Dev et al., 2013). For e.g in wheat crop Zero tillage proved to be best to control weeds and increase in yield also took place (Jat et al., 2013).

\section{Intercropping}

Its very effective and efficient method to control weeds. In this method, different crops are sown together and they utilize the resources by giving tough competition to weeds leading to poor weed growth (Shah et al., 2011).

This method also decreases cost of weeding which leads to higher net income by lowering input cost. For e.g intercropping of crops like legumes, cucurbits, sweet potato etc. suppress the growth of weeds and also they help to reduce the risk of soil erosion. 


\section{Green Manuring or cover crop}

Cover crops helps to suppress weeds by shading effect (Mohler et al., 2012) or through the allelopathic effect (Das 2008). Use of cover crops in combination with organic fertilizers helps to enhance growth of fungi, bacteria or mycorrhizae which is helpful for crop but helps to eliminate growth of weeds. On the other hand, green manure incorporation into field during the tillage time inhibits weed growth (Kruidhof et al., 2011). For e.g in rice crop incorporation of green manure Sesbania suppress weeds through allopathic or its shading effect (Yadav et al., 2010).

\section{Seed treatment}

Treatment of seed with growth promoters $\left(\mathrm{GA}_{3}\right)$, soaking and drying of seeds, heating treatment etc. lower weed population. For e.g treating of seeds of sorghum crop with Fusarium oxysporum help to control weeds efficiently (Elzein et al., 2006).

\section{Crop density}

It is considered as one of the most important component to suppress weed growth. Optimum plant population in the field provides competition to weeds and inhibit their growth by occupying space or taking available nutrients (Meena et al., 2010).

\section{Fertilizer application}

Application of fertilizer in proper amount, at proper time and at proper place helps to reduce weeds as the main crop will gain all the nutrients (Dubey 2014).

\section{Irrigation number and time}

Pre- sowing irrigation helps to reduce weed growth (Verma 2014). For e.g three irrigations given at CRI, tiller stage and flowering stage helps to reduce population of Phlaris minor (Das and Yaduraju, 2007).

\section{Mechanical Control}

\section{Thermal weed control}

It is done with the help of fire, flames, hot water etc. (Ascard et al., 2007). They work very effectively to eliminate weeds. They donot have any residual effect on soil like herbicides nor they disturb soil as done in case of cultivation. The success of this whole process basically depends upon temperature, time and energy (Ascard et al., 2007).

\section{Flame weeding}

In this technique propane burners are used to kill the weeds. Extreme heat leads to damage of cell wall of weeds and leaves of weeds also get burned leading to stoppage in growth of weeds (Singh 2014). It's a very time saving method as plants wither and die within a short period of time in this method.

\section{Slashing}

It's a pre- planting operation. In this practice of weed control the fields are slashed before sowing. And even after harvest, weeds can be slashed so that seed formation donot occur (Senarathne et al., 2011).

\section{Mulching}

Its best way to control weeds without the use of herbicides (Verma and Singh 2008). Most of the weeds can be lowered by the two types of mulches viz. newspapers (Singh 2014) and black polythene (Goswami and Saha 2006). Besides this mulching can also be used to solve problem of erosion, evaporation, improves soil moisture content, control diseases etc. 


\section{Soil solarization}

In this technique, soil temperature is raised by covering the soil with polythene film (black or transparent). And due to increase in temperature decrease in weed growth occurs. For effective activity of this process, weather must be suitable means warm and moist. Rise in soil temperature cause problems in membrane structure, protein and enzyme activity of weeds leading to their death (Arora and Tomar 2012).

\section{Biological Control}

In India, basic way to control weeds is herbicides or in some areas weeds are removed manually. And these ways to control weeds are laborious, time consuming, costly and even cause harm to soil as well as environment. Then to solve all the above mentioned problems a new way called biological control came into highlight in which insects, plant pathogens, nematodes etc. means living creatures and their toxic products are used to suppress the growth of weeds (Tiwari et al., 2013). It's an ecofriendly method and is not too much expensive. In India this method is basically used to control Partheniumhysterophorus (Kumar and Ray 2011).

\section{Chemical Control}

In this strategy of weed control herbicides or inorganic chemicals are used to kill weeds. Herbicides can be applied as soil application or as foliar spray. From the time of Green Revolution farmers are using more or more chemicals to kill weed growth or to gain more profit. Herbicides may be considered as one of the most effective way to control weeds but it has lot of negative aspects also as they degrade the soil and are not eco- friendly. Their use for long time makes them resistant to weeds. Therefore, their optimum use is good but using these chemicals on a large scale harm environment which is an alarm of danger.

\section{Integrated Weed Management (IWM)}

The main challenge in front of agricultural or weed scientists is development of one such approach which is less costly, highly effective, non- time consuming and less laborious. Production cost of weeding operations is very high as it's done manually and it directly leads to increase in cost of production. Due to improper weed management practices country is losing a lot annually. Cost of production can be decreased by adopting proper weed management practice with high efficiency. The need of the hour is to find a labour free weed management approach to attain the target of sustainable crop production. Then a new approach called INM was developed in which two or more weed control methods are used in combination to control weeds. IWM is effective, less input and efficient weed management approach which is now an important part of agriculture system (Riemens et al., 2007). It may be considered as long term weed management approach in which chemical, biological, mechanical or cultural methods are used in integration (Kewat 2014). For e.g in case of wheat crop, use of pre and post emergence herbicide along with hand weeding gave best results as compared to using chemicals alone.

Every year due to weeds hectares of crop is destroyed. Approximately $70-80 \%$ loss in yield occurs in different crops. Farmer should follow integrated weed management as this method is very environment friendly and in this inorganic chemicals are used but in very low amount means optimum amount of chemicals are used along with cultural and mechanical methods to affect weed control. Farmers in India are adopting chemical weed 
control method which are very effective, ideal and practical. But alone use of chemicals or herbicides is degrading the quality of soil as well as is major cause of environmental pollution and many health hazards. So it's high time to move towards such an approach which is eco- friendly. Government as well as extension workers must make farmers aware about IWM.

\section{References}

Arora, A. and Tomar, S. S. 2012. Effect of soil solarization on weed seed bank in soil. Indian J. Weed Science.44 (2): 122-123.

Ascard, J., Hatcher, P. E, Melander, M. K. 2007. Thermal weed control and non chemical weed management. Principles, Concept and Technology. CABI, London, UK.

Cici, Z. H., Adkins, S. and Hanan, J. 2008. A canopy architectural model to study the competitive ability of chickpea with sowthistle. Annals of bot- London.101: 1311-1318.

Das, T. K. and Yaduraju, N.T. 2008. Effect of soil solarization and crop husbandry practices on weed species competition and dynamics in soybean- wheat cropping system. Indian J. Weed Science.40 (1\&2): 1-5.

Das, T. K. and Yaduraju, N.T.2007. Effect of irrigation and $\mathrm{N}$ levels on grassy weed competition in wheat and comparative eco- physiology of Phalaris minor and Avenasterilis ssp. Leudoviciana wheat. Indian J. Weed Science. 39: 178-184.

Das, T. K., Tuti, M. D., Sharma, R., Paul, T. and Mirja, P. R. 2012. Weed management research in India: An overview. Indian Journal of Agronomy.57 (3 IACSpecial Issue): $148-156$.

David, A., Mortensen, J., Egan, F., Bruce, D. M., Mattew, R. R. and Smith, R. G.
2012. Navigating a Critical Juncture for Sustainable Weed Management. Bio. Science.62: 75-84.

Dev, D., Vivek, Singh, S. P. and Kumar, R. 2013. Weed management studies in wheat with herbicide under different establishment methods. Indian $J$. Agronomy. 58 (2): 215- 219.

Dubey, R.P. 2014. Integrated Weed Management - an approach. In Training Manual Advance Training in Weed Management, held at DWSR, Jabalpur, India on 14- 23 January, pp. 19- 21.

Elzein, A, Kroschel, D. J. and Leth, V. 2006. Seed treatment technology: An attractive delivery system for controlling root parasitic weed Striga with mycoherbicide. Bio-control Science and Technology. 16: 3- 26.

Goswami, S. B. and Saha, S. 2006. Effect of organic and inorganic mulches on soilmoisture conservation, weed suppression and yield of elephant foot yam. Indian J.Agronomy. 51 (2): 154156.

Jat, R. K., Banga, R. S. and Yadav, A. 2013. Resource conservation techniques and pendimethalin for control of weeds in durum wheat cultivars. Indian J. Weed Science.45: 93- 98.

Kewat, M. L. 2014. Improved weed management in Rabi crops. National Training onAdvances in Weed Management pp. 22- 25.

Kruidhof, H., Bastiaans, M. L. and Kropff, M. J. 2008. Ecological weed management by cover cropping: effects on weed growth in autumn and weed establishment in spring. Weed Research. 48: 492- 502.

Kumar, S. and Ray, P. 2011. Evaluation of argumentative release of Zygogramma bicolorata for biological control of Parthenium. Crop Protection. 30: 587591. 
Meena, R. S., Singh, M. K. and Singh, B. 2010. Effect of seed rate andweed management on weed and yield of late sown zero-till wheat.National Symposium on Integrated Weed Management in the Era ofClimate Change, held at NAAS, New Delhi on 21-22 August, p. 14.

Mohler, C. L., Dykeman, C., Nelson, E. B. and Ditommaso, A. 2012. Reduction in weed seedling emergence by pathogens following theincorporation of green crop residue. Weed Research.52: 467477.

Oerke, E. C. 2006. Crop losses to pests. The J. Agricultural Science. 144: 31-43.

Riemens, M. M., Widge, R. V. D., Bleeker, P. O. and Lotz, L. 2007. Effect of stale seedbed preparation and subsequent weed control inlettuce on weeds. Weed Research. 47: 149-156.

Shah, S. N., Shroff, J. C., Patel, R. H. and Usadadiya, V. P. 2011. Influence of intercropping and weed management practices on weedand yields of maize. International J. Science and Nature. 2: 47-50.

Sharma, A. R. 2014. Weed management in conservation agriculturesystemsproblems and prospects. National Training on Advances inWeed Management pp. 1-9.

Sindhu, P. V., Thomas, C. G. and Abraham, C. T. 2010. Seedbed manipulations for weed management in wet- seeded rice.
Indian J.Weed Science. 42(3\&4): 173179.

Singh, R. 2014. Weed management in major kharif and rabi crops. National Training on Advances in Weed Management. pp. 31-40.

Teasdale, J. R., Mangum, R. W., Radhakrishnan, J. and Cavigelli, M. A. 2004. Weed seedbank dynamics in three organic farming croprotations. Agronomy J. 96: 1429-1435.

Tiwari, A., Meena, M., Zehra, A. and Upadhyay, R. S. 2013. Efficacy of Alternaria alternata as bioherbicide against weed species. Int. Conf.on Global Scen. Of Trad. Syst. of Medi., Ayurveda, Agriculture and Education, RGSC, Barkachha BHU, 21-22 January, pp. 498-01.

Verma, S. K. 2014. Enhancing sustainability in wheat productionthough irrigation regimes and weed management practices in easternUttar Pradesh. The Ecoscane. 6: 115-119.

Verma, S. K. and Singh, S. B. 2008. Enhancing of wheat productionthrough appropriate agronomic management. Indian Farming. 58(5):15-18.

Yadav, D. B., Yadav, A. and Punia, S. S. 2010. Long term effect ofgreen manuring and herbicidal use on weed dynamics and productivity of rice-wheat cropping system. Nat.Symp. on IWM in the Era of Climate Change, held at NAAS, New Delhi on 21-22 August, pp. 9.

\section{How to cite this article:}

Harmanpreet Kaur, Gursharnpreet Singh Brar and Poonam Pandurang Shete. 2019. A Review on Different Weed Management Approaches. Int.J.Curr.Microbiol.App.Sci. 8(08): 2854-2859. doi: https://doi.org/10.20546/ijcmas.2019.808.328 